\title{
ONKO VAPAALLA SIVISTYSTYÖLLÄ TULEVAISUUTTA?
}

TIMO TOIVIAINEN (2002)

Vapaan sivistystyön visiot. Castrénilaista laatuviiniä uusissa tammitynnyreissä.

Helsingin kaupungin suomenkielinen työväenopisto

Timo Toiviaisen viimeinen teos tuo mieleeni Euroopan kulttuurirahaston kirjan "Onko koulutuksella tulevaisuutta?" 1970luvulta. Siinä kansainvälinen tutkijaryhmä tutkaili koulutusjärjestelmän tulevaisuutta. Välineinä olivat tulevaa yhteiskunta- ja koulutuskehitystä käsittelevät skenaariot. Toiviainen on työskennellyt samaan tapaan. Vaikka hän on kirjoittanut teoksensa yksin, on sen synnyssä keskeisesti mukana keskustelut ja haastattelut muiden asiantuntijoiden kanssa. Skenaarioita hän ei esitä, mutta hänen visioissaan on kyllä aineksia mahdollisille skenaarioiden tekijöillekin. Itse hän nimittää teostaan "tutkielma-asiakirjak-si",ja sitä onkin vaikea sijoittaa mihinkään yhteen luokkaan. Kirjassa on mukana tieteellistä analyysia ja tulevaisuuden tutkimusta mutta myös henkilökohtaisia muisteluksia ja kannanottoja. Kokonaisuuden yhdistää juuri Toiviaisen tietämys ja persoona.

Kirjan kustantaja Helsingin suomenkielinen työväenopisto lähestyy 90 vuoden ikää. Opisto on rehtori Risto Kuosmasen esipuheen mukaan halunnut tuoda kirjan kautta panoksensa Vapaan sivistystyön osaaminen ja pätevyys (VSOP)-hankkeeseen. Opistoa voi tästä teosta kiittää. Toivon että malli yleistyy.

Toiviainen tarkastelee vapaata sivistystyötä monesta näkökulmasta ikään kuin askel kerrallaan. Ensimmäisenä askeleena toimii Zachris Castrénin perinnön tarkastelu. Castrénin yhden miehen komitea "Valtio ja vapaa kansansivistystyö" (1929) ja sen snellmanilainen tausta osoittautuvat hedelmälliseksi lähtökohdaksi sivistystyön nykyisten haasteiden tarkastelulle. Edelleenkin on kysymys siitä, että sivistystyön tulisi olla mukana eriarvoisuuden ja väkivallan ehkäisyssä ja torjunnassa. Yhteiskunta on muuttunut, mutta ei niin perinpohjaisesti että tämä tehtävä olisi hävinnyt. Vapaan sivistystyön asemassa on toki tapahtunut institutionaalisia muutoksia. Aikuiskoulutuksesta on tullut erityisesti pohjoismaissa peruspalvelu, ja aikuisopiskelussa on velvoiteopiskelun piirteitä. Valtion ja vapaan sivistystyön suhde on siis ajankohtainen pohdinnan kohde. Miten keskinäinen luottamus säilytetään, miten onnistuu vapaan sivistystyön autonomian turvaaminen? Castrénia koskevan luvun lopussa, kuten useassa muussa luvussa, on vielä lukijalle säästetty jokerikysymys: Mitä Castrén ei sanonut?

Kolme seuraavaa lukua käsittelevät vapaan sivistystyön vaiheita toisen maailmansodan loppumisesta vuoden 1998 lakiin vapaasta sivistystyöstä. Luvut ovat lyhyitä, niin lyhyitä että voin kuvitella historiallisesti suuntautuneen lukijan voivan niiden lyhyyttä arvostellakin. Toiviaisella on kuitenkin erinomaiset edellytykset nähdä olennainen. Hän on kirjoittanut väitöskirjansa näistä vuosista Euroopassa, joihin hän on Suomessa niin lukijana kuin tekijänäkin perehtynyt. Luku päättyy optimistisesti, kun vapaan sivistystyön järjestöt ja poliitikot soutavat yhteisen veneen lopulta satamaan. Toiviainen hieman vierastaa sitä, että vapaan sivistystyön lakiin tulivat mukaan liikunnan koulutuskeskukset ja kesäyliopistot. Itse olen mm. juuri OISE:ssa, jossa Toiviainen esitti väitöskirjansa, joutunut vastaamaan kysymyk- 
seen, eivätkö kirjastot kuulukaan Suomessa vapaan sivistystyön piiriin?

Kolmas askel on asiantuntijoiden haastattelut. Tavoitteena on nostaa keskusteluun ne avainkysymykset, jotka vapaa sivistystyö tänään kohtaa. Keskustelukumppaneina ovat Helsingin suomenkielisen työväenopiston johtokunnan jäsenet, aineryhmien johtavat opettajat eli "pedagogit", kolme eri tehtävissä olevaa "castrénilaista", kaksi ulkopuolista rehtoria ja neljä valtakunnallista asiantuntijaa. Viimeiseksi mainitut Toiviainen profiloi hyvän elämän ja enemmistön puolustajaksi, symbolista isänmurhaa harkitsevaksi, ota tai jätä - tilanteessa ihmiseen uskovaksi ja vapaan sivistystyön muutoksen kummajaisesta koulutusjärjestelmän osaksi jäsentäväksi, mutta huomattakoon arvorationaaliseksi osaksi. Jo nämä profiloinnit kertovat, että kirjoittaja tavoittaa haastattelujen avulla keskeiset ongelmat. Kirja on syytä lukea, jos on kiinnostunut ketä nämä meidän monien tuntemat persoonat ovat. Opistoväen haastattelut kertovat yksityiskohtaisemmin ja käytännönläheisemmin, mitkä ovat ongelmat ja haasteet joita ei voida paeta. Osin ne ovat koko maassa yhteisiä, osin pääkaupunkiseudun erityisluonteeseen liittyviä.

Seuraavaksi Toiviainen käsittelee niitä yhteiskunnallisia voimia, jotka ovat sivistystyön taustalla ja jotka liikuttavat sitä. Lähtökohtanaan hänellä on Anthony Giddensin ja Ulrich Beckin käsitykset globalisaatiosta. Siten tarkastelu ei jää makrotasolle, vaan myös ihmisten arkielämän muutosta tutkaillaan. Luku on varsin lyhyt, mut- ta jälleen kirjoittaja onnistuu poimimaan olennaiset asiat. Sitä kuvaa näyte alaotsikoista: riski, traditio, perhe, demokratia, aatteet, uskonnot, poliittinen valta, nationalismi, kriisit ja kriisien jälkitilat sekä filosofiat. Selväksi tulee, että olemme haasteellisessa tilanteessa. Samat voimat, jotka ovat edistäneet vapaa sivistystyön kehitystä voivat sitä myös rajoittaa.

Luku Sivistystyön lähtökohtia ja identiteetin aineksia perustuu runsaaseen lähdekirjallisuuteen ja Helsingin suomenkielistä työväenopistoa koskevan asiakirja-aineiston analyysiin. Toiviainen nostaa näkökulmakseen tasa-arvon tavoitteen ja sen paluun mahdollisuuden. Hän toteaa, että kansainvälisten kokemusten perusteella koulutus ja sivistys kasautuvat niille, joilla sitä jo ennestään on runsaasti ellei mihinkään interventioon ryhdytä. Johtopäätös on hyvin ajankohtainen valmistauduttaessa aikuisten koulutustason kohottamisohjelmaan, Noste-ohjelmaan.

\section{HYVÄN ELÄMÄN KOLMIKANTA}

Hyvän elämän kolmikannaksi Toiviainen nostaa seuraavat jännitteet: kansalaisuus vs. työ, sivistys vs. koulutus ja yhteisöllisyys vs. yltiöyksilöllisyys. Toiviaisen valinnat ja niiden perusteet ovat selvät. Siten niistä olisi myös helppoa ja hedelmällistä keskustella. Tarjoan harjoitusapua. Ensinnäkin eikö palkkatyöhön osallistumisen voi nähdä myös osana kansalaisuutta, ainakin Asko Suikkasen "työmarkkinakansalaisuus"-käsitteen kautta? Toiseksi mielestäni aikuiset eivät hevin alistu ulkoa annettuihin koulutustavoitteisiin, vaan opiskelevat omien intressiensä ja mieltymystensä mukaisesti. Siten täsmäkoulutustakin saatetaan käyttää sivistymisen. Kolmanneksi eikö juuri yksilöllisyyttä jos mitä tarvita nyky-yhteiskunnassa? Toki olen samaa mieltä, että sen pahin vihollinen on juuri yltiöyksilöllisyys.

Näkökulmia sivistystyön suunnitteluun on kirjan pisin luku. Lähtökohtana on ei enempää eikä vähempää kuin postmodernismin haaste tiedolle ja moraalille. Toiviainen lainaa Peter Jarvisin sosiologista päätelmää: 'Todellakin, edistynyt kapitalistinen järjestelmä on nielaisemassa kitaansa kasvatuksen kulttuuriset arvot" (s. 113). Haasteellisempaa lähtökohtaa ja kontekstia suunnittelulle on vaikea kuvitella. Toiviainen pohtii sivistyspolitiikan mahdollisuutta Parlamentaarisen aikuiskoulutustyöryhmän tarjoaman Skyllan ja Kharybdiksen, taloudellisen tuen ja ohjaamisen maastossa. Sen jälkeen hän käsittelee suunnittelua, tutkimusta, laatutyötä ja evaluaatiota sekä varoittaa liiasta vaatimattomuudesta. Aikuisväestön ryhmät ovat erinomaisen monipuolisesti ja ilmeikkäästi kuvatut. Hieman jään kaipaamaan sukupuolen ja etnisen ryhmän käsittelyä. Lopussa on taas hauska ja viisas pohdinta siitä, onko ns. tavallista ihmistä olemassa. Olen vakuuttunut, että erityisesti tämä luku tulee kulumaan lukijoiden käsissä.

"Vanhojen ideoiden lämmittelyä ja kysymys" otsikoitu luku on itse asiassa varsin innovatiivinen. Siinä käsitellään hakevaa toimintaa, opintoseteliä, kolmatta sektoria ja vertaisryhmiä sivistystyön uusien lähestymistapojen aineksina. Käsittely on asiantuntevaa ja va- 
laisevaa. Lopun kysymys on ns. tuhannen euron kysymys, josta Toiviainen haluaa muistuttaa kaikkien uusien ideoiden keskellä. Hän haluaa tehdä selväksi, että perimmäisiä kysymyksiä ihmis- ja maailmankuvasta emme voi välttää emmekä ottaa annettuna talouden pakkopaitaa.

Viimeisessä luvussa esitetään kymmenen tulevaisuuden visiota, jotka Toiviainen viisaasti rajaa lähivuosiin. Esitys perustuu kirjan aiempiin lukuihin, mutta varsin lyhyessä tilassa kirjoittaja onnistuu myös uudelleen kiteyttämään keskeisimmät perustelunsa. Siten tasa-arvo, oma traditio, hyvän elämän kolmikanta, identiteetti, muuttunut toimintakulttuuri, laatutyö, tutkimus, opiskelija, opintosuostuttelu ja hyvinvointivaltio ankkurina tulevat käsitellyiksi. Niihin voi lukija ottaa kantaa ja suhteuttaa omat visionsa. Onko vapaalla sivis- tystyöllä siis tulevaisuutta? Millaisille valinnoille se perustuu?

Timo Toiviaisen viimeiseksi jäänyttä kirjaa voi lämpimästi suositella laajalle lukijakunnalle. Se ei ole vain mallikas tutkimus, vaan myös viisas kirja, jossa uskalletaan esittää olennaisia kysymyksiä ilman pelkoa tai kyynisyyttä.

\section{Ari Antikainen}

